\title{
Rевевсн автіск: Knowledge level of drip irrigation farmers about drip irrigation technology
}

Article Chronicle :

Received :

21.03.2020;

Revised:

23.09.2020;

Accepted :

10.10.2020

KEY WoRds:

Drip irrigation,

Knowledge level, Risk

bearing capability,

Tomato growers
Author for correspondence :

\section{Sushma Sahu}

Department of

Agricultural Extension,

College of Agriculture, Indira Gandhi Krishi

Vishwavidyalaya, Raipur

(C.G.) India

Email: sushklchd@gmail.

com

See end of the article for authors' affiliations
SUMMARY : The present study was carried out during 2013 in the Durg district of Chhattisgarh state. This study was conducted in randomly selected 8 villages of two purposively selected blocks i.e. Durg and Dhamdha located in Durg district. The aim of this study was to assess the risk orientation and level of knowledge of drip irrigation farmers about drip irrigation technology. A total of 128 respondents including 64 drip irrigation farmers and 64 non-drip irrigation farmers were selected randomly. The data collection was done by the use of interview schedule through personal interview. Data were analyzed with help of suitable statistical tools. The findings revealed that majority of the respondents had high risk bearing capability and having high level of knowledge about equipments fitted in DIS. Majority of the DIF were having high level of knowledge regarding drip irrigation technology.

How to cite this article : Sahu, Sushma, Surywanshi, D.K., Khan, M.A. and Sahu, Bhedu Prasad (2020). Knowledge level of drip irrigation farmers about drip irrigation technology. Agric. Update, 15(4): 311-314; DOI : 10.15740/HAS/AU/15.4/311-314. Copyright@2020: Hind Agri-Horticultural Society. 